DOI: $10.52950 / T E .2021 .9 .2 .002$

\title{
PUPILS AS SUBJECTS OR OBJECTS: POLICY CHANGES IN THE AREA OF PUPILS INFLUENCE
}

\author{
LINDA ERIKSSON, GÖRAN BOSTEDT
}

\begin{abstract}
:
The aim of this article is to describe and analyse how policy changes in the three latest Swedish compulsory school, preschool class, and school-age educare curricula affect the political goal of pupil influence. This is done with an interest in implications for utterances of power relations and for didactical considerations for living and learning democracy in school. This article analyses pupil influence by using theories of democracy, power, and didactics. The method used is content analysis. The empirical results show that pupil influence in the curricula is linked to seven concepts: democracy, value, norm, rights, responsibility, influence, participation. Our conclusion is that only small differences exist in terms of the central concepts mentioned in the curricula linked to pupil influence. Secondly, we found a policy shift with respect to the pupils, i.e., viewing pupils as subjects or objects. Thirdly, we found a shift in how learning is viewed in the curricula and the type of didactical questions that are in focus, which illuminates a change in utterances of power relations that challenges possibilities for living and learning democracy in Swedish school education.
\end{abstract}

\section{Keywords:}

Didactics, Policy change, Power, Pupil Influence.

JEL Classification: 128

\section{Authors:}

LINDA ERIKSSON, Department of Education, Mid-Sweden University, Sweden, Email: linda.eriksson@miun.se GÖRAN BOSTEDT, Department of Education, Mid-Sweden University, Sweden, Email: goran.bostedt@miun.se

\section{Citation:}

LINDA ERIKSSON, GÖRAN BOSTEDT (2021). Pupils as subjects or objects: Policy changes in the area of pupils influence. International Journal of Teaching and Education, Vol. IX(2), pp. 14-29., 10.52950/TE.2021.9.2.002 


\section{Introduction}

The aim of this article is to describe and analyse how policy changes in the three latest Swedish compulsory school, preschool class, and school-age educare curricula affect the political goal of pupil influence. This is done with an interest in the implications of utterances of power relations, and with didactical considerations for experiencing and learning democracy in school.

The Swedish Education Act (Skollag, 2010:800, § 4) stipulates that education in the school system should aim at pupils' acquisition and development of both knowledge and values. It should also promote pupils' learning and development. The activities in the school must be designed in accordance with basic/fundamental democratic values and human rights (ibid., §2 and §5) and all education should be carried out in the best interests of the child (ibid., §10). The current Swedish 'Curriculum for the Compulsory School, Preschool Class and School-Age Educare' [LGR 11] reinforces the knowledge and democratic duties by stressing that '[d]emocratic working forms should also be applied in practice and prepare pupils for active participation in the life of the society' (Skolverket, 2011s. 8). Governing documents for Swedish schools stipulate that pupils shall influence their education, including the content, working forms, and methods of instruction. In other words, Swedish schools must ensure that pupils not only learn democracy but also live democracy through educational practice.

The ambition of a democratic school has been pursued by the Swedish school system for a long time. State policy texts emphasising the importance of 'the self-governance of apprentices' appeared as early as 1914 (Folkundervisningskomitténs betänkande angående folkskolan 1914) [Public Education Committee]. Since World War II, the schools' socialisation responsibility for democratic values has always been important, together with its responsibility to impart knowledge and generate a well-educated labour force (Ekman \& Todosijevic, 2003; Englund, 2000; Richardssson, 2010; Selberg, 1999). Pupil influence [elevinflytande] has been an important part of school reform of democratic education methods in Sweden. It has, in recent decades, been motivated by arguments for children's rights, the fostering of democratic values, and participation as a prerequisite for learning (cf. SOU1992:94; SOU1996:22). The Swedish National Agency for Education emphasises' that 'the school's duty to promote learning in children and young people cannot be separated from its democratic duty, since both are promoted by the same general causes' (Skolverket, 2000, p. 14). However, in Sweden today challenges exist to the implementation of the idea of pupil influence in everyday school life (Eriksson, 2019).

Our objective in this article is to illuminate and discuss policy changes in the area of pupil influence between the three latest curricula. Our research interest has been delimited to the three latest curricula for compulsory schools (out of a total of five possible curricula: 1962, 1969, 1980, 1994, and 2011, not including earlier forms of Swedish elementary school systems). The reason for restricting our study to the three latest curricula is that with 'Goals and guidelines for primary school [LGR 80]', a new form of governance occurred in Swedish schools (Lundgren et al., 2004). Berg (2018) argues that the institutional rules for Swedish schools have varied over time, characterised as 'management by regulations' during the 1980s, 'management by instructions' during the 1990s (with elements of results and regulation control), and 'management by result control' during the 2000s. (Lundahl et al., 2013) argue that in the last 30 years Sweden has experienced an educational marketisation, i.e., a shift towards neoliberal education policy, even though the idea of social inclusion and equality still prevails. Pupil influence in Swedish schools has also been linked to questions regarding fulfilment of the schools' knowledge and learning duties. In LGR 80, the question of knowledge focused on learning and pupil activity (Carlgren, 2012). In Swedish school reforms during the 1990s, and formulated in 'The 1994 Curriculum for the Compulsory School System' [LPO 94], the concepts of learning and knowledge were similar. Focus also shifted from teaching to learning (Skolverket, 2007; SOU1992:94, 1992; SOU1996:22, 1996). Pronounced difficulties for teachers and school leaders in interpreting and implementing LPO 94, i.e., the gap between 
policy formulation and policy realization (Knill \& Tosun, 2008; Lindensjö \& Lundgren, 2000), as well as a political wish to emphasise the knowledge commission, led to a new curriculum (LGR 11 ) in 2011. The aim was to strengthen the national knowledge commission. Instead of defining goals locally, as in LPO 94, only planning and design of teaching should be formed localy (Skolverket, 2011). But this did not change the school's overall knowledge and democracy duties in any important way (Wahlström, 2015).

In Sweden, research has been conducted on how societal changes affect school democracy policy (see e.g Englund, 2005; Englund, 1995). Policy shifts in the areas of knowledge and learning have also been illuminated and discussed in relation to different purposes of education and what type of knowledge that is promoted (Biesta, 2006, 2007, 2009; Carlgren et al., 2009; Wahlström, 2009). Englund and Solbrekke (2015) have illuminated changes in policy when it comes to teacher autonomy and responsibility. However, studies of policy changes in curricula in the area of pupil influence are missing.

Policy research on education for democratic citizenship is carried out in Sweden (Hjelmer \& Rosvall, 2017), in Scandinavia (Print et al., 2002), and internationally (Arai, 2019; Osler \& Starkey, 2006). Sant (2019) has examined how democratic education is conceptualized within educational research. She finds eight major versions that emerge. Six of them are prodemocratic education (liberal, deliberative, participatory, multicultural, critical, and agonistic) and two are anti-democratic education (elitist, neoliberal). She found few studies for the period 2006-2017 examining the functioning of democratic educational policies, which led her to conclude that further research in the area is desirable. She also argues for further research on democratic pedagogies that position students as in-process or de-facto democratic citizens, depending on whether the democratic education is conceived as education for or education through democracy. This is in line with Biesta (2003, p. 59), where he argues that we should not only understand democracy as a problem for education, but that we should also understand democracy as being itself an educational problem.... This implies that the question for democratic education is not about how to 'create' or 'produce' democratic citizens, but about how to create opportunities for action, for being a subject, both in schools and other educational institutions, and in society as a whole.

Andersson (2019, p. 150) argues that:

education, as a vital part of the school's democratic assignment, should function to democratize meaning-making and learning, thus making democracy a goal and pedagogical method in itself'. In this article, we address the research area by focusing on the question of living and learning democracy in Swedish schools through pupil influence.

\section{Pupils influence: Democracy, policy, power, and didactical considerations}

Our interest in policy change in the area of pupil influence as a way to live and learn democracy requires an initial presentation on different models of democracy as well as perspectives on policy, power, and didactics. Models of democracy can be divided into three main groups: elitist, participatory, and deliberative models (cf. Dahl, 1989; Englund, 2003). Translated to the question of pupil influence, the elitist model involves an emphasis on formal student participation, i.e., organized and institutionalised forms of political participation such as a class or school council or other collective decision-making forums (Andersson, 2019). The participatory model involves an emphasis on students' active participation and/or pupil-active work processes in every-day schoolwork. The deliberative model involves an emphasis on shared discussions and socialisation processes related to democratic values (Roth, 2000).

Policy can be understood as 'a course of action intended to accomplish some end' (Heclo, 1972). It is based on one or several ideas as well as institutional arrangements to realise these ideas (Heclo, 1972). Some policies are statements of government objective, or prohibitions, in different areas of society. Policies, whether distributive, redistributive, or regulatory, can thereby be conceived as the main product of the political system (Knill \& Tosun, 2008). Policymaking is a process often characterised as including a) agenda setting, b) policy 
formulation, c) policy adoption, d) implementation, and e) evaluation (Hill, 2005). In this article, we focus on changes in policy formulation, and their implications for the implementation of pupil influence in Swedish schools.

Analysing public policy change can be done through a top-down model, emphasising the ability of policymakers to produce unequivocal policy objectives and control the implementation process, or a bottom-up model, viewing local policy-relevant actors (such as headmasters, teachers, and students) as central actors in policy delivery, and viewing implementation as negotiation processes within networks (Lipsky, 1980; Mazmanian \& Sabatier, 1983). Hybrid models, integrating elements of both these models, also occur (Hill, 2005). We are interested in analysing policy change in the area of pupil influence because of its implications for power relations in education, as well as didactical considerations in teaching practice. Our interest rests on a viewpoint retrieved from curriculum theory. Curriculum theory pinpoints the question of 'What counts as knowledge?'(Hopmann, 2015; Wahlström, 2015). Sundberg $(2005,2012)$ describes four different approaches to curriculum analysis: socio-cultural, neo-pragmatic, poststructuralist, and critical-interpretative. Our perspective is the critical-interpretive approach.

Analysis of didactical considerations depends on what types of didactical questions are viewed as important. In the Anglo-Saxon and English-speaking tradition, the question of teaching design is central (Westbury, 2010). The American tradition focuses on transmission of a certain culture in a society, while also giving room for autonomy in achieving goals and carrying out teaching (Westbury, 2010). A continental tradition, and critical constructive didactics in particular, focuses on the questions of 'what' and 'why' (Klafki, 1997). It acknowledges education's relationship to the democratization of society at large, and assumptions about the goals of education are included (Blanketz, 1985; Klafki, 2010). This is done without considering a particular ideal for education. The content of education and how that could contribute to fulfilling appointed duties of education are the focus, rather than the specific way of working or how the goals should be achieved. Sfard (1998) describes learning perspectives using two metaphors, participation and acquisition. Participation focuses on action, mastering specific ways of thinking, and occurs in a social community. Acquisition is about pupils' incorporation of knowledge, facts, and concepts.

Didactical considerations in education cannot be separated from the question of power. To describe and discuss questions of didactics and power in education and teaching, it is necessary to understand power in a three-dimensional view (Eriksson, 2019). Lukes (2005) describes power as i) the ability to push through one's opinions by taking part in making decisions ('power over decision-making'), ii) the ability to affect what issues are discussed or not discussed ('power over agenda'), and iii) the ability to influence how others think ('power over thoughts'). With this perspective, didactical considerations relating to power are not limited to the teachers' or pupil's ability to make decisions, but also comprises what questions emerge on the agenda as didactical considerations. Lukes' model of power also makes it possible to discuss how learning and knowledge is facilitated, and the possibility to 'live' or/and 'learn' democracy. In this sense, understanding power as 'power to' (Morriss, 2002) is important. 'Power to' means a capacity and ability to accomplish something in a specific context (Morriss, 2002). This focuses more on power as a possibility to act, instead of an understanding of power as 'power over', i.e., a position giving the possibility to execute power over others based on a situation of dependency. This is an important distinction in the context of education and teaching, where pupils are always subordinated to the commission of their school and teacher's responsibility to teach, but on the other hand are expected to participate in the learning process by influencing their education's content, working forms, and methods of instruction. 


\section{Research design and data collection}

To accomplish the purpose of the study, we used a mixed-method approach, including both content analysis and quantitative text analysis. Content analysis (Krippendorff, 2019; Neundorf, 2017) can be divided into three stages: (1) selection of focus texts, (2) coding the text, and (3) interpretation of the results. All three stages have been used in this study. We selected focus texts by choosing curricula; coded texts by analysing and determining substantive concepts used in relation to pupil influence; and, finally, interpreted the results by analysing whether policy change occurred.

The analysis of the texts occurred in four steps (cf. Boström \& Bostedt, 2020). We read through the text several times, to get a sense of the content in which pupil influence was mentioned. We then divided the text into meaning units (i.e., substantial concepts in relation to mentions of pupil influence) and conducted a descriptive quantitative text analysis. We thereafter compared the use of important condensed meaning units/substantial concepts in relation to pupil influence in the three curricula, and analysed similarities and differences in content. Finally, we met and discussed the analysis to reach a consensus. This resulted in further refinement of themes, which produced a final thematisation of concepts. The authors then confirmed the reliability and validity of the analysis of the qualitative data by a) comparisons of analyses and interpretations of the same data with each other (internal reliability), and b) in collaboration we discussed collected data against relevance for pupil influence (internal validity). (Krippendorff, 2019)

\section{Figure 1. Research design}

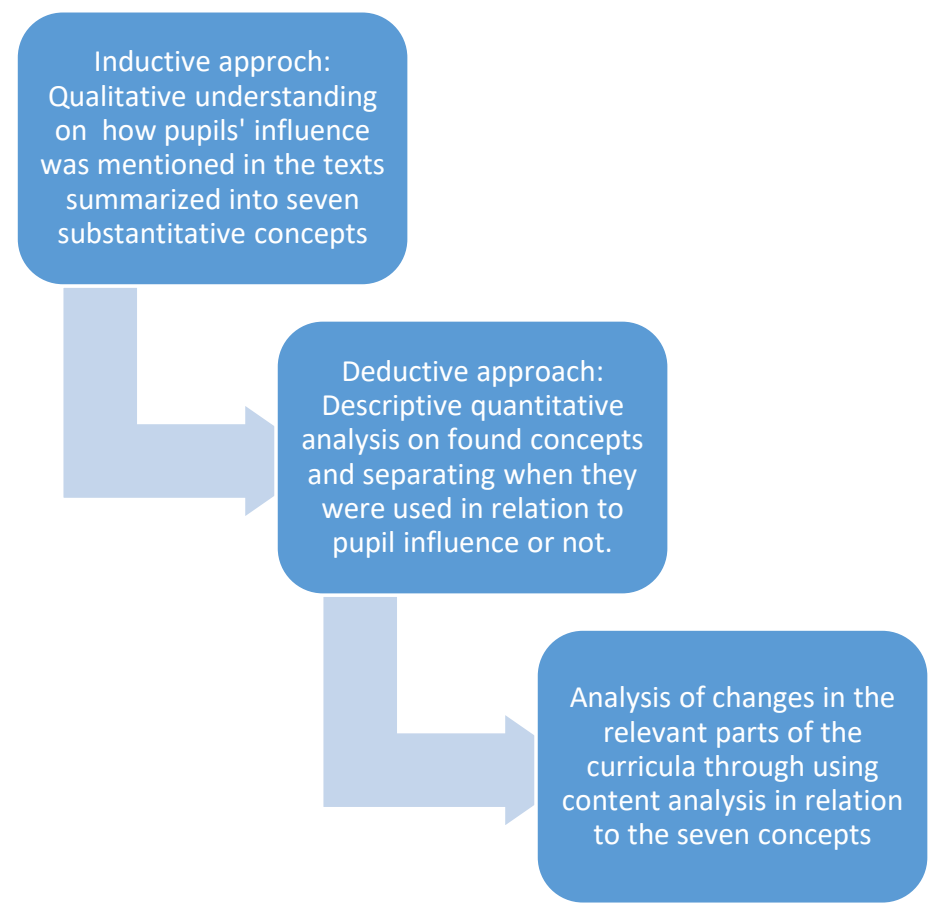


The empirical material consisted of the relevant portions of the curricula for the compulsory school, preschool class, and school-age educare from years 1980, 1994, and 2011. For the current curriculum (LGR 11), it consisted of the introductory portions of the curriculum, i.e., the parts including, among other things, comments on norms, values, pupil responsibilities, and influence. In both LGR 80 and LPO 94, the syllabi are not included in the curriculum. They are documents published separately. As a result, most of the curriculum is covered by the pages listed below. In LGR 80, pages 15-53 were the subject of analysis; in LPO 94, chapters 1 and 2, pages 1-17; and in LGR 11, chapters 1 and 2, pages 5-19. We have used the latest Swedish versions of each curriculum, and refer to these versions by year: LGR 80 (1980), LPO 94 (2006), and LGR 11 (2019). The sixth version of LGR 11 (2019) includes additional material regarding pupil responsibilities and influence. The Swedish versions are used to facilitate correct comparisons among the curricula. The quotations used from the curricula in the below presentation are collected from the existing official translation of LPO 94, from 2006, and LGR 11, from 2018. We have ensured that quotes used from LGR 11 (2018) are also found in the Swedish version of 2019. There is no official translation of LGR 80, so translation of these quotations was made by the authors and reviewed by a professional language editor. For readability and comprehension, the abbreviations LGR 80, LPO 94, and LGR 11 have been used throughout to mark the different curricula and the years they were added, but also for spatial reasons, as titles of some curricula are long.

As stated above, we used a content-analysis method (Neundorf, 2017). To analyse the text, we read the selected parts of the curricula and registered keywords used in connection with pupil influence in education. The collected keywords were classified into main groups and constituted concepts for descriptive-quantitative text analysis. The concepts were democracy, value, norm, rights, responsibility, influence, participation. In the quantitative text analysis, a basic form of the words was chosen, to include different possible forms of each word. For example, searches for democracy include results for democratic, democratically, democracy, and democratization. The term influence, as used here, includes both the meaning of influence and its effect, i.e., an assumption that policy recommendations concerning influence also impact patterns of action in schools with relation to pupil influence. The words 'influence' and 'impact' are often used in the curricula in the same sentence. No distinctions are made between the words., leading us to assume that they are used as equivalent concepts. After conducting the quantitative text analysis, we read the curricula texts once more. After analysing how and in which contexts words were used in different parts of the curricula, we distinguished between uses of the words relevant to pupil influence and those referring to other themes.

The number of search results for selected concepts varies among the three curricula, where the words are used (headings not included) in connection with pupils or with relevance to the issue of pupil influence. In some cases, it was difficult to determine whether the use of the concept was relevant for pupil influence or not. However, this has not been a problem for the analysis of the material, because questionable categorisation issues were very few, with no important consequences for the overall interpretation of the text. 'Responsibility' is most frequently used as a word, in relation to pupil influence, and 'norm' the least. 
Table 1. Frequency of selected concepts in three Swedish curricula. Total number of uses, and the number of uses in connection with pupils or the issue of pupil's influence.

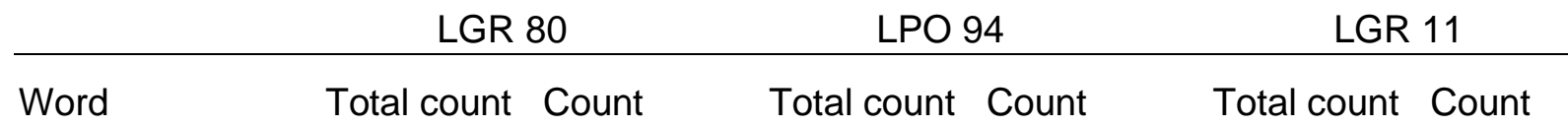

$\begin{array}{lrrrrrr}\text { Democracy } & 17 & 7 & 10 & 7 & 17 & 7 \\ \text { Value } & 26 & 1 & 19 & 4 & 27 & 3 \\ \text { Norm } & 4 & 0 & 5 & 2 & 5 & 3 \\ \text { Rights } & 3 & 1 & 4 & 3 & 6 & 4 \\ \text { Responsibility } & 30 & 8 & 36 & 15 & 39 & 14 \\ \text { Influence } & 9 & 2 & 11 & 9 & 26 & 16 \\ \text { Participation } & 0 & 0 & 3 & 2 & 6 & 5\end{array}$

Much, but not all, of the writings on pupils' influence in the three curricula are very similar in content. As the interest of this article is in policy changes, these similarities are presented in the article but not used for further analysis and discussion. What remains are the concepts that show a change in content.

\section{Empirical results}

The three latest Swedish national curricula for primary and lower-secondary schools (LGR 80, LPO 94, LGR 11) state that the public-school system should be based on a democratic foundation and that activities should be designed in accordance with fundamental democratic values. The texts in the introductory chapters of all three curricula include similar comments on democracy, human rights, knowledge skills and values, equal access to education, the nationwide equivalence of education in every school form, the importance of school-parents interaction, support for pupils with special needs, gender equality, environmental issues, etcetera. The similarities in the text are especially strong between LPO 94 and LGR 11. Both have the same wording concerning, for example, the rights and obligations of pupils. But there are also differences between the three curricula. In the following text, we present the curriculum content in relation to the keywords found regarding pupil influence: democracy, value, norm, rights, responsibility, influence, and participation.

\section{Democracy}

The passages in the curricula concerning democracy deal with the concept both in terms of how to include democracy as a form of decision, as well as how to implement democratic values in the school's work and work democratically in practical everyday activity. LGR 80 (1980, p. 15) states that 'The curriculum reflects the social view and the human view of democracy: man is active, creative, can and must take responsibility and seek knowledge ....' The school's role in this is also to foster a democratic way of acting in practical everyday activity through schoolwork, in collaboration with parents (ibid, pp. 15-18). This is achieved with student-active working methods, among other things (ibid, pp. 46-47) and the importance of pupils' organizing themselves in different associations. Student associations are considered to encourage the formation of groups around common interests. Thereby, pupils' will be 
accustomed to working in different contexts, following decisions made in a democratic order, and working in democratic forms (ibid, p. 50).

In LPO 94 and LGR 11, there are many similar wordings regarding democracy issues. LGR 11 (2019, p. 7; cf. LPO 94, 2006, p. 5) states that 'It is not in itself sufficient that teaching only imparts knowledge about fundamental democratic values. Democratic working forms should also be applied in practice and prepare pupils for active participation in the life of society'. This is argued to develop pupils' ability to take personal responsibility. By taking part in the planning and evaluation of their daily teaching, and being able to choose courses, subjects, themes, and activities, pupils 'will develop their ability to exercise influence and take responsibility' (ibid). As in LGR 80, LPO 94 and LGR 11 comment that democracy is based on both democratic values and forms of decision-making, as well as implementing democratic values in the school's work and working democratically in practical everyday activities. Everyone who works in the school must 'show respect for the individual pupil and organise daily work in democratic ways.' (LPO 94, 2006, p. 8; cf. LGR 11, 2018, p. 10). Teachers have to 'prepare the pupils for participating in and sharing the joint responsibilities, rights and obligations that characterise a democratic society.' (LPO 94, 2006, p. 14; cf. LGR 11, 2018, p. 14). In LGR 11, democratic principles are linked to participation and influence. The educational program should provide pupils with an opportunity 'to develop familiarity with democratic principles, working methods and processes through participation, exercising influence and taking responsibility in the activities.' (LGR 11, 2018, p. 19-20).

\section{Value}

Value and values recur quite frequently in the curricula, but are not often linked to the issue of pupils' or pupil influence. The texts are very similar between the different curricula. The term is most often used in a general societal context, for example, linked to democracy or human rights. In some cases, it relates to pupils, stating that practical action must be implemented during the school day. 'The school should actively and consciously influence and stimulate pupils into embracing the common values of our society and express these in practical daily action.' (LPO 94, 2006, p. 8; cf. LGR 80, 1980, p. 18; cf. LGR11, 2018, p. 6)

\section{Norms}

Norms are not mentioned in LPO 80 in the context of pupils, or pupil influence issues. Text formulations closest to this concept refer to an adult's responsibility to anchor ethical norms in the children's personality (LPO 80,1980 , p. 20). This is also repeated, in similar terms, in LPO 94 (2006, p. 9). However, LPO 94 broadens the perspective to a simultaneous societal and student perspective. According to the curriculum, a goal to achieve in compulsory school must be that the pupils both know the laws and norms of society as well as 'their own rights and obligations in school and society' (ibid, p. 10). This is repeated in LGR 11 (2018, p. 12), where it is emphasised that it is the school's responsibility to ensure that pupils gain knowledge of society's laws and norms, human rights, and democratic values in school and society. The teachers then have to 'work together with the home in the upbringing of the pupils and clarify the school's norms and rules as a basis for work and co-operation' (ibid, p. 11).

\section{Rights}

Rights are mentioned in LGR 80 in connection to democracy and human rights and freedom. 'The activities in the school as well as in society, in general, are based on political decisions that have been made in a democratic order. ... At the same time as the school adheres to this, it must make clear that one must never, with the help of society's laws, suppress fundamental human freedoms and rights' (LGR 80, 1980, p. 19). In LPO 94 (2006, pp. 4-5), the same 
references are found in the text, but with the addition that the school must clarify students' rights and obligations, and that the teachers have a responsibility to 'prepare the pupils for participating in and sharing the joint responsibilities, rights and obligations that characterise a democratic society.' (ibid, p. 14). In LGR 11 (2019, p. 5), the same reasoning is found as in LPO 94, but with the addition that the school has to clarify what rights and obligations both students and guardians have.

\section{Responsibility}

Responsibility is an oft-mentioned concept in LGR 80, LPO 94, and LGR 11. However, the term is most often used in contexts that cannot be linked to the issue of student influence. When used in relation to pupil influence, it most frequently occurs (with some interesting exceptions) in sentences where the concepts democracy and influence are also found. 'It is not in itself sufficient that teaching only imparts knowledge about fundamental democratic values. Democratic working forms should also be applied in practice and prepare pupils for active participation in the life of society. This should develop their ability to take personal responsibility.' (LGR 11, 2018, p. 7; cf. LPO 94, 2006, p. 5)

In LGR 80 (1980, p.19), schools and families are highlighted as responsible for children to develop into democratic and responsible individuals. Both LPO 94 and LGR 11 comment that students should be given opportunities to take initiative and responsibility, but that it is the school's and guardians' joint responsibility for students' schooling to create the best possible conditions for development and learning, and that the school should strive for students to take personal responsibility for their studies (LPO 94, 2006, pp. 13-14; LGR 11, 2019, pp. 13-14). LGR 11 (2018, p. 14) also highlights the responsibility of all employees in the school to 'support the pupils' ability and willingness to both influence and take responsibility for the social, cultural and physical school environment'. LGR 11 hereby specifies the issue of responsibility in three specific areas. The curricula also state that teachers have to ensure that students gradually receive more and larger independent duties and increased personal responsibility (ibid, p. 13) and that teachers in their teaching should give students 'the opportunity to develop familiarity with democratic principles, working methods and processes through participation, exercising influence and taking responsibility in the activities.' (ibid, pp. 19-20)

Some parts of the curricula also emphasize student responsibility. LGR $80(1980$, p. 25) states that 'Activity and responsibility, not a passive service attitude, must characterize the students' role in the school.' This applies in general, in relation to the school, and the teaching. Students must also, according to the curriculum, be allowed to apply time-consuming work methods and to plan and take responsibility for a larger duty (LGR 80, 1980, p. 38; LGR 11, 2019, p. 7). However, student responsibility is more frequently mentioned in LPO 94 and LGR 11 than in LGR 80. In LPO 94 (2006, p. 5) and LGR 11 (2018, p. 7), use similar terms to place the emphasis on students' participation in the planning and evaluation of their daily teaching as a way to develop their ability to exercise influence and take responsibility. Teachers should 'take as their starting point that the pupils are able and willing to take personal responsibility for their learning and work in school,' (LGR 11, 2019, p 14; cf. LPO 94, 2006, p 13). LGR 11 (2019, p. 13) emphasises that the democratic principles of being able to influence, take responsibility, and be involved, must apply to all students.

\section{Influence}

The concept of influence is found linked to students in only two places in LGR 80. Firstly, in a discussion of the role of guidance counsellors (Swedish abbreviation, 'syo') and what influence teachers and guidance counsellors should have, rather than students. The teachers and guidance counsellors are viewed as 'a strong counterweight to the influence of the home environment, peers, the mass media, etc.' (LGR 80, 1980, p. 40) The teachers' educational 
mission is emphasised to constitute a counterweight to other socialization actors such as family and peers. Secondly, influence is mentioned together with the concept of responsibility; 'The school has a duty to give students increased responsibility and co-influence as they age and mature.' (LGR 80, 1980, p. 15) In the quote, influence is referred to as 'co-influence', thereby stating that possibilities for pupil influence are divided with other actors.

In both LGR 80 (1980, p. 22) and LPO 94, the school is the emphasised body for action. 'The school should make clear to pupils and parents the goals of the education, the requirements of the school and the rights and obligations of pupils and guardians. A basic precondition for pupils and guardians to exercise influence is that the individual school clearly sets out its goals, its content and its working structures.' (LPO 94, 2006, p. 5). Literally the same wording reappears in LGR 11 (2019, p. 6). The school is further stated, in LPO 94 (2006, p. 13), to have the duty of developing students' ability to take personal responsibility. LGR 11 specifies schools' responsibility to 'promote the pupils' ability and willingness to take responsibility and influence over the social, cultural and physical school environment' (LGR 11, 2018, p. 14). LGR 11 thus states a field for student influence that is broader than that referred to by LPO 94, and includes the physical as well as cultural and social environment.

After LPO 94 and LGR 11 comment on the school's duty and function, the writings on influence and democracy move on to focus on the pupils. 'By participating in the planning and evaluation of their daily education, and exercising choices over courses, subjects, themes and activities, pupils will develop their ability to exercise influence and take responsibility.' (LPO 94, 2006, p. 5; LGR 11, 2018, p. 7) LPO 94 (2006, p.13) assumes that students can and want to take personal responsibility for their learning and schoolwork. In other parts of LGR 11, however, the perspective from LPO 80 returns, limiting the issues of democracy and influence to the fact that someone other than the students is in focus. Students are reduced to passive objects. In LGR 11, the students' representatives are the teachers and the principal, instead of LGR 80's focus on the school. The teacher must 'be responsible for ensuring that all pupils can exercise real influence over working methods, forms and contents of education' (LGR 11, 2018, p. 14), and to ensure that this influence grows with increasing age and maturity. The principal is responsible for the results of the school and, within given constraints, has special responsibility for ensuring that: 'the working methods at the school are developed so that active pupil influence is encouraged' (ibid, p. 17).

\section{Participation}

The word 'participation' does not occur in LGR 80. In LPO 94, it is commented that 'The democratic principles of being able to influence, take responsibility and be involved should embrace all pupils' (LPO 94, 2006, p. 13), and 'prepare the pupils for participating in and sharing the joint responsibilities, rights and obligations that characterise a democratic society' (ibid, p. 14). These formulations also recur verbatim in LGR 11. In LGR, however, the use of the term is extended to also include an individual self-responsibility and focus for the student: 'takes personal responsibility for their studies and working environment' (LGR 11, 2018, p 13). Participation as individual responsibility must also, according to the curricula, be a keyword in teaching (ibid, pp. 19-20). In this case, responsibility of the school and the teachers is shifted to the students.

\section{Conclusions}

We have presented the occurrences of the seven relevant concepts in the curriculum texts. There are many similarities among the studied curricula concerning concepts related to pupil influence in schools. However, there are also some significant differences.

Democracy is most often referred to both in relation to societal decision-making and in implementing democratic values in schools. In LGR 80, the school and the family are both 
subjective actors implementing values, while students are passive objects. However, at the same time, student associations are highlighted as something important. In LPO 94 and LGR 11 , the organization of teaching, student-centred working methods, is highlighted as something important. In LGR 80, pupils' active participation in learning is separated from democracy. Democracy is also described as making decisions in teaching practice. In LPO 94 and LGR 11 , prerequisites for learning are brought together with knowledge and democracy.

Values are commented on equally in the three curricula. The school and the teachers are the active subjects, while students are the passive objects for these actions. No policy change appears between the curricula in relation to this concept. Norms are not mentioned explicitly in LGR 80, but the text highlights adult responsibility for the students. The concept is mentioned with similar wording in LPO 94 and LGR 11. The policy change that takes place with LGR 11 is that, in addition to a general societal perspective regarding the importance of norms, teachers have a responsibility to clarify school norms and rules. In LPO 94, norms are described as a goal to strive towards; LGR 11 focuses on what to do for the pupils. This is objectifying pupils, specifying what to do for them, rather than look upon pupils as active subjects.

Rights are commented on in LGR 80 in connection to the societal aspects of democracy. This is repeated in the other two curricula, but with the additional comments that schools and teachers have a responsibility to clarify students' rights and obligations. This also includes questions concerning school and teaching. Education in a societal context is not in focus. A point of view according to which the school and the teachers are the active subjects, and the student's passive objects, returns again here. Rights are no longer a goal that pupils should be prepared for, or able to understand and handle, but something to be clarified for students.

Responsibility occurs frequently in the three curricula, but most often in contexts unconnected to the issue of student influence. It is often also used in sentences along with the concept of democracy. The school, the teachers, and families have the responsibility to educate the students, so they become responsible individuals. The students are passive objects for this education. In all three curricula, however, some writings highlight the students as active subjects in issues of responsibility. The policy differences between the three curricula regarding responsibility are small. The only difference is that responsibility in LPO 94 is linked to a goal for pupil education and means more generally, in practice, having influence and participating in learning. In LGR 11 it is described as a proposition for pupils.

Influence is commented on very sparingly in LGR 80 , only in relation to the influence of educators over students. In LPO 94, the school is highlighted as an active actor developing students' abilities to take responsibility, and in LGR 11 are specified the areas within which this is to take place. In the two later curricula, however, some passages also highlight the students as active subjects. According to LGR 11, teachers should inform and clarify different aspects of every-day schoolwork (working methods, forms and contents of education) to enable pupil participation. In LPO 94, participation is described both as a goal and a means in teaching and education.

Participation is not commented on in LGR 80, but appears in the other two curricula. Participation is seen as a democratic principle that must be maintained. But LGR 11, in comparison to LPO 94, considers student participation a responsibility for the teachers in their teaching, and the individual responsibility of the students. The policy change that takes place with LGR 11 is that the concept of participation is broadened to explicitly include several actors. The students are, in LGR 11, described as both passive objects and active subjects.

LGR 80 states that schools, as institutions, must give students possibilities for taking responsibility and experiencing co-influence. It does not elaborate as to how. Instead, the curriculum expresses the view that the school has the responsibility, through schoolwork, and in collaboration with families, to stimulate students' desire for activity, and to nurture students' sense of responsibility, good working and leisure habits, and democratic behaviour (LGR 80, 
1980 p. 15). LGR 80 (1980, p. 45) also states that the school should seek to do this through collaboration and consultation among students, staff, and school management.

By summarizing the use of the seven concepts in the three curricula, we can conclude that LPO 94 expresses a view of learning in which pupils' active participation is a prerequisite for knowledge formation. LPO 94 also stresses the importance of real influence (i.e., that the democratic ambitions must go beyond information and participation to include involvement and influence). LPO 94 thereby challenges the unilateral power of the teaching profession and the school as an institution. In LGR 11, pupils are mostly, but not always, defined as objects, rather than subjects. They should be encouraged (by someone) to further develop their education and be informed (by someone). Within this scope, they should have the opportunity (not the right) to take initiative (not take part in decisions). LGR 11 takes thereby a decidedly more passive approach to pupils' ability compared with LPO 94, an approach more in line with the perspectives represented in LGR 80 but including a teacher-student focused, rather than institutional approach. In our view, LGR 80 thereby represents an educational institutional approach to pupil influence; LPO 94 represents a knowledge/ learning approach; and LGR 11 represents a classroom leadership/teaching approach. We want to emphasise and illustrate this important conclusion on policy shift with the below quotes, extracted from the same section of the three different curricula.

The curriculum reflects democratic social view and human view: man is active, creative, can and must take responsibility and seek knowledge to cooperate with others, understand and improve the living conditions of themselves and their fellow human beings. The school's content and working methods must be so designed as to promote this view of society and individuals. The school has a duty to give students increased responsibility and co-influence as they progress their rising age and maturity. (LGR 80, 1980, p.15)

The democratic principles of being able to influence, take responsibility and be involved shall embrace all pupils. Development of pupils' knowledge and social awareness requires that they take increasingly greater responsibility for their own work as well as for the school environment and that they are also able to exercise real influence over their education. According to the Education Act, it is incumbent on all who work in the school to work for democratic working structures (Chap. 1 § 2). (LPO 94, 2006, p. 13)

The democratic principles of being able to influence, take responsibility and be involved should cover all pupils. Pupils should be given influence over their education. They should be continuously encouraged to take an active part in the work of further developing the education and kept informed of issues that concern them. The information and the means by which pupils exercise influence should be related to their age and maturity. Pupils should always have the opportunity of taking the initiative on issues that should be treated within the framework of their influence over their education. (LGR 11, 2018, p. 13)

LPO 94 states that pupils should have influence, in the school, over the contents of education and the working methods and structures. In LGR 80 and LGR 11, the question of pupil knowledge formation moves from pupils' active participation to the responsibility of a school (LGR 80) or professional/teacher (LGR 11). The teacher should, according to LGR 11, prepare pupils for participation and co-responsibility, as well as for the rights and obligations that characterise a democratic society, which can be seen as an objective of pupil influence and responsibility. This is possible by informing them of these points. The question, then, is whether and how this perspective on the current Swedish curriculum for compulsory school (LGR 11) in terms of pupil influence (i.e., pupils as passive objects for information) can sustain the opportunity to live and learn democracy in schools (i.e., pupil influence as a means for didactical considerations and power relations). 


\section{Discussion}

Our aim in this article was to describe and analyse policy changes with regard to the political goal of pupil influence. This was done with an interest in implications for didactical considerations and utterances of power relations. Our interest in policy change is based on the changing institutional rules for Swedish schools during the latest 30 years, in terms of new governing philosophies as well as the marketisation of the school system (Lundahl et al., 2013). Our interest in policy change is also based on the need for education, as a vital part of a school's democratic duty, to function to democratise meaning-making and learning, thus making democracy a goal and pedagogical method in itself (Andersson, 2019; Biesta, 2003). Our results show, firstly, only small changes in terms of the central concepts mentioned in the curricula linked to pupil influence. Participation and norms are not discussed, and influence is only indirectly discussed (co-influence) in LGR 80, but otherwise all concepts recur in all three curricula. Secondly, we found a policy shift in the three curricula in respect to the pupils, i.e., viewing pupils as subjects or objects. That was most evident in relation to the concepts of norms, rights, and participation. Thirdly, we found a shift in how learning is viewed in the curricula, and what type of didactical questions are in focus, which illuminates a change in utterances of power relations that challenges the possibility to live and learn democracy in school education.

The differences among the three curricula, in terms of a policy shift in pupil perspectives, have implications for a discussion of power, i.e., viewing pupils as subjects or objects in or of the schools learning processes. In LGR 80 and LGR 11, the pupils were primarily described as objects for other school actors' actions; in LPO 94, the pupils were described as subjects participating in the contents of education and the working methods and structures of everyday life in school. A subject has the power to participate and take personal responsibility for the learning processes. An object is situated relative to others who have the power over their learning processes and subjects. In LGR 80 , the power relations are illuminated as the school system's 'power over' the pupils in decision-making. In LPO 94, with its focus on learning and knowledge, the curriculum opens up to understand the importance of pupils' 'power to' influence the learning processes in a specific context. It is connected to both the democratic and knowledge duties, as well as those of teaching and learning. In LGR 11, the perspective of power is once again limited to 'power over' the pupils, as the students become objects for teachers' actions and decision-making regarding the contents of education, and the working methods and structures of everyday life in school. This has implications for didactical considerations as well as for democratic fostering in schools. As Arai (2019) points out, it is important to focus on how subjectification is illuminated in civic education, and in what way it includes possibilities for self-transformation. The perspectives of 'power over' and 'power to' (Morriss, 2002) can also be discussed in relation to different conceptions of democracy (Dahl, 1989; Englund, 2003), i.e., a shift from a primarily elite model of democracy in LGR 80 (educational institutional approach) to a participatory/deliberative model in LPO 94 (knowledge/ learning approach) and then back again to a primarily, but somewhat different, elite model in LGR 11 (classroom leadership/teaching approach).

The impact of the policy changes, when it comes to didactical considerations (Westbury, 2010), could in LGR 80 be understood as anchored in an Anglo-Saxon tradition of didactics focusing on how teaching should be organized. In terms of power dimensions (Lukes, 2005), this represents power over the decision-making and power over the agenda. In LPO 94, a continental tradition is obvious, where the didactical questions of what and why are focused on in relation to teaching, and where teachers and pupils are active subjects. With a continental-didactical approach, the school's democratic duty is linked to questions about knowledge and learning. This incorporates all three power dimensions, i.e., power over the decision-making, power over the agenda, and power over thoughts. The latest curriculum, LGR 11 , again seems to focus on the didactical question of how teaching should be organized. This time, it is not carried out and motivated from a wider institutional school perspective, but in a school leadership approach to teaching, regarding how to fulfil educational goals. This could 
be understood through an American, didactical tradition, but with a tilt towards the knowledge duty. The focus is on knowledge commission. Teachers shall prepare pupils for participation and co-responsibility by encouraging them to take an active part in the work of developing their education, and keeping them informed of issues that concern them.

In LGR 11, an educational goal of pupil responsibility is underlined, rather than the possibility for students to take responsibility for their learning. According to the curricula, teachers' main responsibility is to clarify the pupils' possibilities rather than involve them in dialogues on the contents of education and the working methods and structures of everyday life in school. Learning is seen as a process of acquisition rather than participation. This creates a limited space to live and learn democracy in teaching. Pupil influence, as a prerequisite for learning and acquiring knowledge, is limited to the teacher's responsibility to inform and clarify their considerations for pupils. This is something profoundly different from involving pupils in the learning processes and discussions about knowledge and values. Democratic values and knowledge are taken more for granted. The policy shift we have described complicates the dynamic and complex processes of learning and living democracy in schools, and thereby fulfilling the education goals stated in The Swedish Education Act and in the current Swedish curriculum for the compulsory school, preschool class, and school-age educare.

\section{References}

Andersson, P. (2019). The school as a public space for democratic experiences: Formal student participation and its political characteristics. Education, Citizenship and Social Justice, 14(2), 149164.

Arai, Y. M. D. T. a. P. E. i. J. (2019). Modern Democratic Theories and Political Education in Japan. Educational Studies in Japan, International Yearbook (No. 13), 67-79.

Biesta, G. (2003). Demokrati: Ett problem för utbildning eller ett utbildningsproblem. Utbildning och demokrati, 12(1), 59-80.

Biesta, G. (2006). Bortom lärandet: Demokratisk utbildning för en mänsklig framtid (G. Sandin, Trans.). Studentlitteratur.

Biesta, G. (2007). The education: Socialisation conundrum or 'Who is afraid of education' Utbildning och demokrati, 16(3), 25-36.

Biesta, G. (2009). Good Education in an age of measurement: On the need to reconnect with the question of purpose in education. Educational Assessment, Evaluation and Accountability, 21(1), 33-46.

Blanketz, H. (1985). Didaktikens teorier och modeller. HLS Förlag.

Boström, L., \& Bostedt, G. (2020). What about Study Motivation? Students' and Teahcers' Perspectives on What Affects Study Motivation. International Journal of Learning, Teaching and Educational Reserach, 19(8), 40-59.

Carlgren, I. (2012). Kunskap för bildning? In T. Englund, E. Forsberg, \& D. Sundberg (Eds.), Vad räknas som kunskap? Läroplansteoretiska utsikter och inblickar i lärarutbildning och skola (pp. 118-139). Liber.

Carlgren, I., Forsberg, E., \& Lindberg, V. (2009). Perspektiv på den svenska skolans kunskapsdiskussion. Stockholms universitets förlag.

Dahl, R. A. (1989). Democrazy and its critics. Yale University Press.

Education, N. A. f. (2018). Curriculum for the compulsory school, preschool class and school-age educare 2011 (Revised 2018 ed.). Nordstedts Juridik.

Ekman, J., \& Todosijevic, S. (2003). Unga demokrater. Fritzes.

Englund, T. (2000). Deliberativa samtal som värdegrund: Historiska perspektiv och aktuella förutsättningar. Skolverket. 
Englund, T. (2003). Skolan och demokratin: På väg mot en skola för deliberativa samtal? In B. Jonson \& K. Roth (Eds.), Demokrati och lärande (pp. 49-74). Studentlitteratur.

Englund, T. (2005). Läroplanens och skolkunskapens politiska dimension. Daidalos.

Englund, T. (Ed.) (1995). Utbildningspolitiskt systemskifte. HLS Förlag.

Englund, T., \& Solbrekke, T. D. (2015). Om innebörden av lärarprofessionalims. Pedagogisk forskning i Sverige, 20(3-4), 165-194.

Eriksson, L. (2019). Elevinflytande i gränslandet mellan didaktik och makt: en studie av undervisningspraktiken i tre grundskolor, Mittuniversitetet].

Folkundervisningskomitténs betänkande angående folkskolan (1914). Nordiska.

Heclo, H. (1972). Review Article: Policy Anlaysis. Brittisch Journal of Political Science, 2(1), 83-108. https://doi.org/https://doi.org/10.1017/S0007123400008449

Hill, M. (2005). The Public Policy Process. Pearson/Longman.

Hjelmer, C., \& Rosvall, P.-Å. (2017). Does social justice count? 'Lived Democracy' in mathematics classes in diverse Swedish upper secondary programmes. Journal of Curriculum Studies, 49(2), 216-234.

Hopmann, S. (2015). 'Didaktik meets Curriculum' revisited: historical encounters, systematik experience, empirical limits. Nordic Journal of Studies in Educational Policy(1).

Klafki, W. (1997). Kritisk-konstruktiv didaktik. In M. Uljens (Ed.), Didaktik (pp. 215-228). Studentlitteratur.

Klafki, W. (2010). The significance of classical theories of bildung for a contemporary concept of allgeminbildung. In I. Westbury, S. Hopmann, \& K. Riquarts (Eds.), Teaching as a reflective practice: The German didaktic tradition (pp. 85-107). Routledge.

Knill, C., \& Tosun, J. (2008). Policy Making. In D. Caramani (Ed.), Compartive Politics (pp. 495-519). Oxford University Press.

Krippendorff, K. (2019). Content Analysis: An introduciton to Its Methodology. Sage.

Lindensjö, B., \& Lundgren, U. P. (2000). Utbildningsreformer och politisk styrning. Stockholm universitets förlag.

Lipsky, M. (1980). Street-Levele Bureaucracy: The Dilemmas of Individuals in the Public Service. Russel Sage Foundation.

Lukes, S. (2005). Power: A radical view (2 ed.). Palgrave MacMillan.

Lundahl, L., Erixon Arreman, I., A-s, H., \& Lundström, U. (2013). Educational Marketization the Swedish Way. Education Inquiry, 4(3). https://doi.org/10.3402/ edui.v4i3.22620

Lundgren, U. P., Román, H., Lundahl, C., \& Lindskog, E. (2004). Läroplaner och kursplaner som styrinstrument. Skolverket.

Mazmanian, D., \& Sabatier, P. (1983). Implementation and Public Policy. Scott.

Morriss, P. (2002). Power: A philosophical analysis (2nd ed.). Manchester University Press.

National Agency for Education. (2006). Curriculum for the compulsory school system, the pre-school class and the leisure-time centre Lpo 94 (R. Brian, Trans.). The Swedish National Agency for Education.

Neundorf, K. (2017). The content Analysis Guidebook. Sage.

Osler, A., \& Starkey, H. (2006). Education for Democratic Citizenship: a Review of Reserach Policy and Practice 1995-2005. Reserach Papers in Education, 24, 433-466.

Print, M., S, Ø., \& Skovgaard Nielsen, H. (2002). Education for Democratic Processes in Schools and Classrooms. European Journal of Education, 37(2), 193-210.

Richardssson, G. (2010). Svensk utbildningshistoria: Skola och samhälle förr och nu. Studentlitteratur. 
Roth, K. (2000). Democracy, Education and Citizenship. Stockholm Institute of Education Press.

Sant, E. (2019). Democratic Education: A theoretical Review (2016-2017). Review of Educational Research, 89(5), 655-696. https://doi.org/10.3102/0034654319862493

Selberg, G. (1999). Elevinflytande i lärandet, Luleå tekniska universitet].

Sfard, A. (1998). On two metaphors for learning and the dangers of choosing just one. Educational Researcher, 27(2), 4-13.

Skollag (2010:800).

Skolverket. (2000). En fördjupad studie om värdegrunden. Skolverket.

Skolverket. (2006). Läroplan för det obligatoriska skolväsendet, förskoleklassen och fritidshemmet Lpo 94. Fritzes.

Skolverket. (2007). Skolverkets lägesbedömning 2007: Förskola, skola och vuxenutbildning. Skolverket.

Skolverket. (2011). Läroplan för grundskolan, förskoleklassen och fritidshemmet 2011. Skolverket.

Skolöverstyrelsen. (1980). Läroplan för grundskolan. Allmän del. Mål och riktlinjer, kursplaner. Liber.

SOU1992:94. (1992). Skola för bildning 1992:94. Fritzes.

SOU1996:22. (1996). Inflytande på riktigt: Om elevers rätt till inflytande, delaktighet och ansvar. Fritzes.

Sundberg, D. (2005). Skolreformernas dilemman: En läroplansteoretisk studie av kampen om tid i den svenska obligatoriska skolan, Växjö universitet].

Sundberg, D. (2012). Läroplansteori: Några samtida utvecklingslinjer. In T. Englund, E. Forsberg, \& D. Sundberg (Eds.), Vad räknas som kunskap? Läroplansteoreiska utsikter och inblickar i lärarutbildning och skola (pp. 80-99). Liber.

Wahlström, N. (2009). Mellan leverans och utbildning: Om lärande i en mål- och resultatstyrd skola. Daidalos.

Wahlström, N. (2015). Läroplansteori och didaktik. Gleerups.

Westbury, I. (2010). Teaching as a reflective practice. What might didaktik teach curriculum? In I. Westbury, S. Hopmann, \& K. Riquarts (Eds.), Teaching as a Reflective Practice. The German Didaktik Tradition (pp. 15-39). Routledge. 